DOI: $10.31866 / 2410-1915.21 .2020 .208264$

UDC 7.017.4:687.53

\title{
HIGHLIGHTS ON THE THEORY AND PRACTICE OF CHROMATOLOGY AND ITS APPLICATION IN THE ART OF HAIRDRESSING
}

\section{Olena Savitska}

PhD student, ORCID: 0000-0003-0905-4243, e.savitskaya1@gmail.com, Kyiv National University of Culture and Arts, 36, Ye. Konovaltsia St., Kyiv, 01133, Ukraine

\section{For citations:}

Savitska, O. (2020). Highlights on the Theory and Practice of Chromatology and Its Application in the Art of Hairdressing. Culture and Arts in the Modern World, 21, 251-263. https://doi.org/10.31866/24101915.21.2020.208264.

The development of chromatology as a scientific basis for the art and design practices has been analysed in this article. The purpose of the article is to study chromatology as a complex of scientific knowledge that had been formed for thousands of years and today is a theoretical and practical basis for solving various creative tasks, including the art of hairdressing. The research methodology is based on the analysis of the formation and development of the science of colour as a phenomenon that contains essential information for science and art, including colour design. The historical and comparative, chronologic methods were applied to show the process of the formation and development of the science of colour; to organise and systematize heterogeneous materials - a systematic approach; to examine the contribution of the men of science and art to the development of chromatology - biographical; to compare the historical data - comparative. The scientific novelty of the study is to analyse the impact of the science of colour on the production and creative practice of colouristic hairstyle design. Conclusions. It was found that the science of colour as a scientific knowledge combines the disciplines of the natural sciences and humanities, which is the basis for the modern scientific approach to work with colour, taking into account its optical, colouring and other characteristics. The development of the science of colour has taken place over the centuries, covering the historical epochs of Antiquity, the Renaissance, Modern, Contemporary history, modernity. The contemporary chromatology is based on the combination of knowledge about physical (light) and psycho-physiological (vision, emotion) phenomena, which are reflected in physics, psychology, physiology, cultural studies, and art history. Design, including the art of hairdressing, referring to the results of interdisciplinary research, reflects the high level of modern comprehension of colour and its wide application in hairstyle.

Keywords: chromatology; colour; hairstyle design; art of hairdressing. 


\section{Introduction}

Colour is one of the specific means of artistic and material culture. It affects the visual perception of the subject environment, creates a certain emotional and psychological state of a person, and systematizes the way he sees the world. People have been interested in the phenomenon of colour for centuries and this interest has been embodied in a number of scientific studies and theories, as well as in the development of the science of colour - chromatology. Ancient philosophers, the Renaissance artists, scientists, philosophers, poets, and artists of Modern and Contemporary history took part in its development. The result of these long-standing research works became the realisation of the possibility of the rational use of constructive, functional and aesthetic qualities of colour in the artistic and material spheres.

The current state of the colour science, in particular, its history, is reflected the works of E. Kirillov (1987), S. Lomov and S. Amanzholov (2018), which perform mainly educational purpose, reveal the general foundations of science, attach to the science the understanding of the aesthetic and semantic dominants of colour in modern practice.

In recent decades, there has been an increasing interest in colouring from the hairdressers, because this is an important part of the designer hairstyles creation. Thus, P. Yurchenko (2008), revealing various aspects of a hairstyle creation, paid attention to the characteristics of colour, namely, the main, complex and additional colour contrasts, their mixing, harmony, and emphasized the issues of colouring as the leading element of the hair-dyeing. The author also gave accent to the cultural aspect of modern hairdressing, which deals with the colouring of hair based on colourimetry, dependence of colour on the physical nature of light.

S. Lubianska (2010) also addressed the issues of colour harmony in the hairstyle design, noting the consistency of purposeful and conscious application in its design (pp. 108-132).

More systematic is the understanding of colour by the expert hairdresser A. Kuvvatov, who outlined in the number of works his own vision of identification of the colour type of a person, as well as the author's techniques of colouring the hair by its main types. So, in the third section of the publication "The art of colour" (Kuvvatov, 2009, pp. 20-144), the author referred to the issue of colour, tone, saturation, lightness, colour wheel, digital system, considered the influence of colour on a person, his colour type (spring, summer, autumn, winter), compositional possibilities of colour, colouring, etc. Despite the fact that the publication is aimed at providing guidelines for the expert hairdressers, there are also important instructions as to the form and mass of colour, indications for colouring; how to use hair colouring tools, materials and techniques. However, the materials published by A. Kuvvatov being relevant at the end of the 1990s - beginning of the 2000s, today should be updated to meet the modern needs of hairstyle design, since there have been proposals for new non-standard colour solutions in recent decades. Chromatology as a theory and practice of modern design, including hairdressing, requires the reviewing from the point of view of the history of formation and development. 
Despite the fact that it is widely used in architecture, fine and decorative arts, and in design in general, the science of colour, being limited to a few studies, has not been sufficiently implemented in the art of hairdressing.

\section{Purpose of the article}

The purpose of the article is to study chromatology as a scientific discipline, which provides the work on colouring with theoretical and practical knowledge - a creative tool for the implementation of the design solutions. The research methodology includes the following methods: the historical, comparative and chronologic methods were applied to show the process of the formation and development of the science of colour; to regulate and systematize heterogeneous materials - a systematic approach; to examine the contribution of the men of science and art to the development of the science of colour - biographical; to compare historical data - comparative.

\section{Main research material}

Colour, which plays a dominant role in the human's perception of information and feelings, is considered in the various aspects: functional, physiological, psychological, constructive, and aesthetical. In design, such properties of colour are embodied in the practice of the creation of the external and internal environment, landscape, clothing, accessories, hairstyles, since the colour solution of any object of design is its organic part. The development of fashion, the diversity of its stylistic trends and image solutions encourages modern designers and image makers to search for full-fledged proposals regarding the modern consumer demand for a design-product, including the beauty industry and hairdressing. In the latter case, it is the possibility to invent an image with a change in hair colour or the introduction of several colours at the same time to form an image. The modern chemical industry can offer a significant colour range of dyes to solve these issues. Therefore, the design of hairstyle comes up with the idea of hair colouring, the invention of original techniques and technologies of this process, as well as suggestions of various colour solutions. This aspect of hairdressing is combined with the other knowledge, such as psychology, physiology, hygiene, aesthetics, art history. Special attention is required to study and systematize the range of issues in colour science - the science of the nature of light and colour. The essential meaning of its mastering belongs to the history of the colour studying, which gives an idea of the spread of this knowledge to the various spheres of human activity, including hairdressing. At the present stage, colour in the design of hairstyle takes a special place.

According to the German researcher G. Zeugner (1974), the study of colour has undergone several stages of its development. Summarising this process, the researcher claims that the first stage was characterized by the lack of a scientific approach, the second - the development of the scientific knowledge in various "private areas", which resulted in the third stage - the creation of scientific systems. 
It is also worth noting that while the study of the qualities of colour and the use of this knowledge in practice has traditionally had a significant output in the work of architects and artists, colour, which is also one of the leading means of image making in hairdressing, remained almost unexplored. The purpose of this article is to prove that in its origins and formation, the study of colour has the same basis and the same paths as the general development of chromatology in other areas of creative work.

As a specific type of knowledge, the science of colour has a fairly significant history. The first addresses to the issues related to the analysis of colour, its study, had the character of philosophical investigations, and the first attempts to understand the colour as a phenomenon can be found in the works of ancient philosophers - the materialist Democritus $\left(5^{\text {th }}-4^{\text {th }}\right.$ century $\left.\mathrm{BC}\right)$, the mathematician Euclid ( $4^{\text {th }}$ century BC), the materialist Aristotle ( $4^{\text {th }}$ century BC), the idealist Plato $\left(5^{\text {th }}\right.$ century $\left.\mathrm{BC}\right)$, which reflect the understanding of the essence of colour based on the analysis of the nature of vision, comparisons of the qualities of black and white, contrasts of light and darkness (Rowe, 1972).

Some ideas of the ancient era about colour passed into the Middle Ages, but the nature of the colour origin remained unknown (Osmankina, 2006).

The foundation of the science of colour was laid by the English physicist Isaac Newton, who relied on the principles of natural science and in the $17^{\text {th }}$ century transferred the subjective perception of brightness and colour to the objective language of numbers, measures and physical law. While studying the sunlight, he discovered that a beam of light passing through a glass lens is refracted, and the image of the rainbow colours is displayed on the surface. The appearance of the spectrum, which was known even before Newton, was explained by the fact that glass seemed to affect white light by changing its colour. He explained the nature of white light as a complex combination of different rays that are refracted differently in glass. The prism decomposes white light into simple components that are mixed to form a white colour. If you select any colour ray from the rainbow spectrum of a prism, such as blue, and pass it through another prism, the colour remains unchanged, and no new decomposition occurs. Something permanent, highlighted by the decomposition of a ray of light into simple colours, the eye does not feel and cannot distinguish a complex colour from a simple one. Newton proved that the refraction of colours in a prism is the spatial distribution of simple colours, which corresponds to a certain number - the index of refraction. Using mathematical and physical methods, Newton (1954) arranged spectral colours in the form of a circle of seven parts for the first time.

Newton's innovative work was the subject of much controversy. One of the opponents of his theory was the German poet Johann Goethe, who wrote the work "Theory of Colours" (1810) (Goethe, 2019).

The idea of J. Goethe's work was that he considered all phenomena related to colour from the point of view of its influence on a person. At the same time, Goethe distinguished the psychological and physiological aspects of this influence, the "sensual and moral effect of colours" took a leading place in his work, and he, for the first time, systematically considered the influence of var- 
ious colour schemes on the psycho-emotional state of a person. Goethe believed that colour can cause emotions, and being derived from light, colour light - emotion are in a causal relationship and are the links of the same chain. Looking at the objects through the prism, Goethe noticed the coloured stripes appearing on the verge of light and dark, and spectral colours - as a contrast between light and darkness. The presence of two opposite poles was considered a characteristic of colours and their manifestations. He compared yellow and its adjacent colours to light, and blue and its adjacent colours - to darkness. He also discovered that when a prism is distanced from an object, the yellow stripe splits into yellow and red, and the blue stripe splits into blue and violet, that is why Goethe considered red to be an amplifier of yellow, and violet - of blue. He observed it in nature. He considered yellow and red colours - warm and active, blue and violet - passive.

The appearance of an additional colour as the next after a long observation of the one, Goethe explained as the natural reaction of the visual organs to the received stimulus. But if there is an additional colour in the field of vision, the eye will rest: with the help of additional colours the balance is achieved, which Goethe considered to be a harmony. He created a colour wheel, where arranged the colours according to his theory of their origin. Depending on the location, he defined the aesthetic effect of colour combinations: the combination of opposite colours as harmonious, the combination of distant ones as distinctive, the combination of neighbouring ones - as inharmonious.

Goethe's criticism of Newton's work was a mistake, which is laid in the difference of their scientific principles and approaches. The law of colours discovered by Newton on the basis of experiments were alien to him, since he considered the subject as a philosopher and artist.

The ideas of the psychological impact of colour and colour harmony put forward by Goethe generated great interest among artists. Goethe's contemporary, painter Philipp Otto Runge, was fascinated by his ideas, continued to study colour. He proposed a system of colours arrangement not on a plane, but in a three-dimensional spherical colour model with meridians and parallels, resembling a globe. One of the poles was marked with white colour, the other with black, and the pure tones of colour ran along the line of the equator. On the meridians, pure colours "passed" a gradual mixing with white and black, which inside the sphere led to their "bleaching" or "darkening", saturation. As an artist, he was interested in low-saturated colours, with an admixture of gray, which was important for the colour perspective (Parramón, 1989).

O. Runge's system of colours arrangement was later improved, but the principle of their location in a three-dimensional system was objectively correct, so it was used by his followers.

In the $18^{\text {th }}$ century, important experiments with colour, in particular experiments with colour rays, were carried out by the English physicist Thomas Young, the founder of the wave theory of light. He recreated light based on red, blue and green colours, and then - the theory of three-component colour vision. Young argued that colour could not be explained only by the physical properties of light, their perception also depends on the eye features, which 
has three different receivers with different sensitivity to certain parts of the spectrum (Buimistru, 2010).

In the $19^{\text {th }}$ century, based on the three-component theory of colour vision by T. Young, the Scottish scientist James Maxwell formed an additive theory of colour formation. According to this theory, all colours can be obtained from red, blue and green rays, and the colour of an object is determined by the degree of surface absorption and reflection of the radiation from different spectral zones. The scheme proposed by Maxwell is a triangle where the three primary colours, which are radiated and located in the corners. White colour appeared on the basis of mixing of the three primary rays. Maxwell's electromagnetic theory of light summarized the theoretical conclusions and practical experiments of many physicists, thanks to which a colour image based on the photographic method was obtained for the first time and a colourimeter was created (Longair, 2008). Despite a number of important discoveries, until the middle of the $19^{\text {th }}$ century, scientific views and theories remained unconnected knowledge. Artists referred to the practice of mixing pigments, which had visual results, and physicists referred to Newton's theory and considered white as the sum of all colours. The solution to the contradictions was the discovery of German physicist and physiologist Hermann Helmholtz, who found that when light rays of different colours are superimposed, their overall surface is always lighter than individual rays. In other words, the sum of all spectral colours is white light. The same results were obtained by adding two spectral colours, namely the pairs of yellow-blue and red-green. He called the process of assembling multicoloured streams of light an additive mixing. H. Helmholtz also found that a mixture of red and blue pigments absorbs some of the light falling on the surface. He called the process of reducing the light flux as a subtraction, and the mixing of pigments - subtractive mixing. These positions formed the basis for scientific justification of the results of various types of mixing. Colour tone, saturation and brightness are three components of colour characteristics proposed by Helmholtz. The scientist also proved the relationship of light and heat radiation and their belonging to the group of electromagnetic phenomena.

As a physiologist H. Helmholtz (1910) considered a number of physiological questions related to colour. The appearance of an after-image, as well as the feeling of gray instead of bright red after a long perception, he explained as the fatigue of the retina.

An important contribution to the development of colour science in the $19^{\text {th }}$ century was made by the German physiologist and physicist Ewald Goering (Maklakov, 2016). He differentiated the doctrine of colour into physical, physiological and psychological areas. E. Goering believed that colour sensations are caused by substances in the visual apparatus that give the impression of an additional colour: yellow - blue, red - green, black - white. Instead of three colours, E. Goering accepted four initial colours, with black and white not being perceived as colours. According to Goering's theory, the result of dissimilation is the appearance of a sense of yellow and red, and the result of the restoration (assimilation) of this substance - green and blue colours. In addition, E. Goering studied and analysed the visual perception of memory and colour constan- 
cy, considered the processes of adaptation and the role of personal experience in evaluating the colour of objects when lighting changes.

Physical optics also became the basis of scientific experiments of Russian academician Sergey Vavilov (2006), who later, in the twentieth century, continued to study the nature of light and colour, in particular the phenomenon of luminescence. Author of more than 150 popular science works, S. Vavilov (2006) relied on the works of prominent thinkers and scientists - R. Descartes, I. Newton, G. Berkeley, J. Goethe, which gives them considerable scientific richness of the content.

The scientific systematization of colours is associated with the name of the professor of physics and chemistry at the Leipzig University, winner of the Nobel Prize in 1909, Wilhelm Ostwald. The founder of modern colourimetry, the theory of colour systematization, he developed a method for purposeful use of colour in any field where it is required. The position of colours based on the complementarity in a circle divided into 24 segments was determined by precise measurements of the ratio of the colour impression and the wavelength obtained by mixing two different colour streams of additional colours. Proposed by Ostwald's colour body in the form of a double cone became the development of Runge's spherical colour model. Ostwald also introduced the name of "absolute colours" for all pure colours and rejected the concept of basic and derived colours. Runge sought to show all colours as a simple geometric shape. Ostwald identified three features of colour perception, with the help of which any colour can be characterized: V - for absolute (pure) colour, $\mathrm{W}$ - for white colour, $\mathrm{S}$ - for black colour. The ratio of these values was represented as an equilateral triangle, which is a longitudinal section of the Ostwald's colour body. By taking the values $\mathrm{V}-\mathrm{W}-\mathrm{S}$, he changed the understanding of colour perception through tone, saturation, and brightness. The colour cone makes it possible to achieve a harmonious colour solution from the simple combinations. The researcher considered the order of colours in the proposed spatial system, their geometric and mathematical relations to be the basis of harmony. In his opinion, equal intervals within colour circle or double colour cone give harmonious colour combinations (Khramov, 1983).

At the same time, personal experience and practical use of colour by some artists caused disagreement with the W. Ostwald's ideas about harmony. As practitioners, they had slightly different results, such as the fact that the harmony of colour combinations depends on various factors, including those that are not represented in the colour circle.

In the second half of the $19^{\text {th }}$ century, German physicist and meteorologist Wilhelm Bezold made a research about colours, based on the proposed colour system in the form of a cone, and the consideration of the issues of colour was addressed to the creative practice in decorative arts and painting (Prokopovych, 2016). Having based on the works of his predecessors - scientists I. Newton, J. Goethe, H. Helmholtz, J. Maxwell, he also took into account the practical experience of artists, with which he was familiar thanks to his relative, the outstanding art critic Gustav Bezold. W. Bezold's merit was an attempt to develop rules of colour harmony through the distribution of colours in decorative rows, 
including the creation of colour triads based on three basic colours - red, yellow and blue. W. Bezold's scientific ideas significantly advanced colour science.

In the twentieth century, art context of the science of colour have been significantly adjusted due to the phenomenon of colour in the works of Johannes Itten (Itten, 2004), Swiss designer, painter and theorist of the Weimar Bauhaus school, his idea significantly changed the approach to the understanding of colour in the artist's creative practice. Together with the new attitude to art education in general, J. Itten (Itten, 2004) sought to develop students' skills of fluency in usage of form and colour as an universal means of creativity. Written on the basis of the lecture course, the work was called "the Art of Colour", where the scientist unveiled the idea of a "colour sphere", which had already had 12 colours. It changed the idea of its possibilities, which affected the work of many artists, architects and designers of the $20^{\text {th }}-21^{\text {st }}$ centuries.

J. Itten (2004) created a kind of colour constructor, which included a colour sphere, colour circle, and colour star. Due to research, he also documented and proved the relationship between colour and shape. Colour analysis and colour construction became an auxiliary source for creating harmonious colour combinations. This is how J. Itten's method has found a wide application in design.

In the twentieth century, the problem of colour became one of the priorities in the creative practice of Wassily Kandinsky - an outstanding painter, a wellknown abstract theorist. W. Kandinsky (2018), who considered colour as one of the elements of artistic language, studied the features of its psychological impact on a person. The main provisions of the colour theory he outlined in the writings about art and in the educational course, which he taught in Bauhaus.

Considering the colour, W. Kandinsky (2018) addressed the categories of paint and form, proclaiming that form can exist independently, whereas colour cannot be infinite; hence, form affects colour. He believed that one form could enhance colour, another could suppress it. Kandinsky distinguished four properties of colour: warm or cold tones, each of which can be dark or light. According to his theory, each colour is endowed with an internal movement directed towards the viewer (eccentric movement), or away from it (concentric movement). Kandinsky (2018) saw an organic connection between the elements of painting - line, point, plane and their colour manifestations. Kandinsky's teachings about colour were completed in the pedagogical system, which is used nowadays.

German researcher G. Zeugner (1974) expressed ideas similar to the ideas of Kandinsky. Studying the colour palette, he claimed that colours lose intensity of vision perception on the following scale: yellow on black, white on blue, black on orange, orange on black, black on white, white on red, red on yellow, green on white, orange on white, red on green. G. Zeugner (1974) analysed the development of the doctrine of colour in its historical stages, the influence of colour on a person as a pattern corresponding to its psychological characteristics, studied a number of types of colour harmonies, and proved the importance of colour standardization for practical work. Almost no attention is paid to the issues of colour creation and colour perception, depending on certain lighting conditions and textures. 
Theoretical generalizations of all available information about colour in the twentieth century were summed up by a French scientist G. Agoston (1987). He addressed the issues of colour perception, its measurements, technical and practical use of colour science terminology, methods for determining colour in the standard colourimetric system of the International Commission on Illumination (CIE), and CIE graphics.

The original scientific version of colour was suggested by A. Zaitcev (1986). He reviewed the history of colour studies, changes in the views on the subject in different historical periods. Based on the fact, that scientists with the presence of means of measuring the wavelengths, however, were unable to analyse the aesthetic nature of colour, because had no methods of scientific research, through which it was possible to determine the emotional and aesthetic properties of colour in works of art, he came to the conclusion that these contradictions draw the line between artistic and scientific exploration of colour.

A. Zaitcev proves that the choice of means of artistic expression (colour contrast, nuance, type of colour harmony) is influenced by the perception and subjective interpretation of the artist, which is an abstraction of colour combinations of reality. The perception of colour by a person is influenced by a number of factors of socio-psychological, cultural, and individual physiological characteristics. The author presented the colour harmony as a consistency of colour shades, derived from consonance, balance, proportionality. According to the author, an isolated combination of colours can be both harmonious and inharmonious, but in the structure of the work of art with a corresponding image content, any colour combinations can be interesting and expressive.

Attention should be paid to the author's statements about approaches to the study of colour harmony. A. Zaitcev (1986) argues that the study of its principles should begin with the general laws of the combination of abstract colours, taking into account their location in the colour wheel.

Taking into account that the author considers the use of colour harmonies in painting, the issue of colour use in design requires similar studying.

History of the science of colour, fundamentals of chromatology, colour in the artificial environment were studied in the works of L. Mironova (2005). Traditionally referring to the reconstruction of a complete picture of the origin of the science of colour, the author revealed its current state on a cultural basis, addressing the problem of colour and colour as a universal experience of combining many factors and an aesthetic problem.

Modern design applies the general principles of colour science. The theory of colour, based on the knowledge of the laws of its functioning, the principles of colours mixing and creating harmony, the visual impact of colours and colour combinations on a person, is able not only to determine the role of colour by its characteristics, but also provide it with a meaningful sense. An example of the application of colour science in the design of the hairdressing work is the system of colouring "Axiom", proposed by a master of international class A. Kuvvatov (2009) from the beginning of 2000s Executive Director of the Studio and Art Director of Keune company, and later Director of the Studio Revlon Professional (2004-2006) and Art Director of ESTEL 
Professional company (2006-2007), he conducted a full testing of this system. "Axiom" is characterized by a wide palette of colours, which, in addition to traditional hair colouring, provides versatile approaches to scientific calculations of colour science. In particular, a special attention was given to the features of using achromatic and chromatic colours, tones, saturation, analysis of colour temperature and colour density, the use of the digital system in accordance with the parameters of the human colour type by the characteristics accepted in hairdressing: "spring”, "summer", "autumn”, "winter”. Using concrete examples, he demonstrated the compositional features of colour in the ratio of the main and additional elements of colour. Discovered by $\mathrm{A}$. $\mathrm{Ku}-$ vvatov (2009) the rules of shape and mass of colour, colour and composition, are, in particular, applied in the face correction. Also, in the process of working with the colour system "Axiom", new tools, techniques of hair colouring were tested.

Thus, a retrospective analysis of the development of colour science, systematization and arrangement of its achievements allow us to apply them in the modern design practices, in particular, the creation of hairstyles.

\section{Conclusions}

Chromatology, as a specific type of knowledge, has a rather significant history. Colour as a phenomenon has been the subject of research since the ancient era. The influence of the colour on human mind and mental life was the subject of speculations by Greek philosophers, in particular Plato and Aristotle. Since the Renaissance, numerous experiments on the issue of colour were carried out by artists, including the outstanding artist and scientist Leonardo da Vinci. With the development of the natural sciences, in particular physics and optics, colour has been the subject of research by many scientists. An outstanding physicist and mathematician I. Newton made important discoveries as far back as in the $17^{\text {th }}$ - the first quarter of the $18^{\text {th }}$ century. The great poet and scientist J. Goethe sought to reveal the "moral and sensual" effect of colour. In our time, chromatology is a science that combines knowledge of nature study, psychology, sociology, philosophy and art history. The first addresses to the issues related to colour had the nature of philosophical research, then later its study moved to the fundamental sciences - physics and optics, and then - in the process of its understanding by the humanities, in particular, art history and psychology.

Modern knowledge of colour is based on the discovery of the interrelations of such phenomena as light, vision, and emotion. The modern colour science has the focus on quite different tools, methods and approaches to phenomena that combine issues of philosophy, physics, psychology, physiology and art history, creating a platform for an interdisciplinary approach to the issue.

The conducted research, which refers to the analysis of colour science in the aspect of hairdressing for the first time, forms an idea of the level of modern scientific understanding of this issue in the mentioned area in general and specifically in the design of hairstyles. 
The promising aspects of such research can be the use of specific colours and colour combinations to form creative hairstyles and, at the same time, new image solutions.

\section{References}

Agoston, G. (1987). Colour Theory and Its Application in Art and Design. Springer [in English].

Buimistru, T. A. (2010). Koloristika: tcvet - kliuch k krasote i garmonii [Colouring: colour is the key to beauty and harmony]. Niola-Press [in Russian].

Goethe, J. (2019). Uchenie o tcvete [The doctrine of colour]. Azbuka [in Russian].

Helmholtz, H. von. (1910). Handbuch der Physiologischen Optik. Voss [in German].

Itten, J. (2004). Iskusstvo tcveta [The art of colour]. D. Aronov [in Russian].

Yurchenko, P. (2008). Koloristika. Formula uspekha [Colouring. Formula for success]. Gorobetc [in Russian].

Kandinsky, W. (2018). Tochka i liniia na ploskosti. O dukhovnom v iskusstve [Point and line to plane]. AST [in Russian].

Khramov, Yu. A. (1983). Ostwald Wilhelm Friedrich. Nauka [in Russian].

Kirillov, E. A. (1987). Tcvetovedenie [Colour science]. Legkoprombytizdat [in Russian].

Kuvvatov, A. (2009). Iskusstvo tcveta [The art of colour] [in Russian].

Lomov, S. P., \& Amanzholov, S. A. (2018). Tcvetovedenie [Colour science]. Vlados [in Russian]. Longair, M. S. (2008, January 25). Maxwell and the science of colour. Philosophical

Transactions of the Royal Society A: Mathematical, Physical and Engineering Sciences,

28, 366(1871), 1685-1696. https://royalsocietypublishing.org/doi/full/10.1098/ rsta.2007.2178. https://doi.org/10.1098/rsta.2007.2178 [in English].

Lubianska, S. P. (2010). Dyzain zachisky [Hairstyle design]. Kondor [in Ukrainian].

Maklakov, A. G. (2016). Obshchaia psikhologiia [General psychology]. Piter [in Russian].

Mironova, L. N. (2005). Tcvet v izobrazitelnom iskusstve [Colour in the visual arts]. Belarus

[in Russian].

Newton, I. (1954). Optika ili Traktat ob otrazheniiakh, prelomleniiakh, izgibaniiakh i tcvetakh sveta [Opticks: Or Treatise of the Reflections, Refractions, Inflections and Colours of light] (S. I. Vavilov, Trans.). Gosudarstvennoe izdatelstvo tekhnikoteoreticheskoi literatury [in Russian].

Osmankina, G. Iu. (2006). Tcvet kak simvol vizualno-materialnogo ideala obshchestva [Colour as a symbol of the visual-material ideal of society]. Omskii nauchnyi vestnik, 10(49), 207-211 [in Russian].

Parramón, J. M. (1989). Color theory. Watson-Guptill [in English].

Prokopovych, T.A. (2016). Osnovy koloroznavstva [Fundamentals of colour science]. Vezha-Druk [in Ukrainian].

Rowe, Ch. (1972). Conceptions of Colour and Colour Symbolism in the Ancient World. Eranos Jahrbuch, 41, 327-364 [in English].

Vavilov, S. I. (2006). Glaz i solntce [Eye and sun]. Amfora [in Russian].

Zaitcev, A.S. (1986). Nauka o tcvete i zhivopis [The science of colour and painting]. Iskusstvo [in Russian].

Zeugner, G. (1974). Uchenie o tcvete: populiarnyi ocherk [The doctrine of colour: a popular essay]. Izdatelstvo literatury po stroitelstvu [in Russian]. 


\title{
ДЕЯКІ ПИТАННЯ ТЕОРІЇ І ПРАКТИКИ КОЛЬОРОЗНАВСТВА ТА ЙОГО ЗАСТОСУВАННЯ У ПЕРУКАРСЬКОМУ МИСТЕЦТВІ
}

\author{
Савіцька Олена Володимирівна
}

Аспірантка, ORCID: 0000-0003-0905-4243, e.savitskaya1@gmail.com, Київський національний університет культури і мистецтв, Київ, Україна

У статті проаналізовано розвиток кольорознавства як наукової основи мистецьких та дизайнерських практик. Метою роботи є дослідження кольорознавства як комплексу наукових знань, які сформувалися впродовж тисячоліть і нині є теоретичним та практичним підгрунтям для рішення різноманітних творчих завдань, у тому числі в перукарському мистецтві. Методологія дослідження полягає в аналізі формування та розвитку кольорознавства як явища, що вміщує суттєву інформацію для науки та творчості, в тому числі колористичному дизайні. Для відстеження становлення, формування, розвитку кольорознавства застосовано історико-порівняльний та хронологічний методи, для впорядкування та систематизації різнорідних матеріалів системний підхід, для вивчення внеску в розвиток кольорознавства діячів науки та мистецтва - біографічний, для порівняння історичних даних - компаративний. Наукова новизна дослідження полягає в аналізі впливу кольорознавства на виробничу та творчу практику колористичного дизайну зачіски. Висновки. 3’ясовано, що кольорознавство як наукове знання поєднує дисципліни природничого та гуманітарного кола, що є підгрунтям для сучасного наукового підходу до роботи із кольором з урахуванням його оптичних, барвникових та інших властивостей. Розвиток кольорознавства відбувався впродовж століть, що охоплює історичні епохи античності, Відродження, Нової, Новітньої історії, сучасності. Модерне кольорознавство грунтується на поєднанні знань про фізичні (світло) та психофізіологічні (зір, емоція) явища, що знайшло відображення у фізиці, психології, фізіології, культурології, мистецтвознавстві. Дизайн, у тому числі перукарське мистецтво, звернувшись до результатів міждисциплінарних досліджень, відображає високий рівень сучасного осмислення кольору та його широке застосування у зачісці.

Ключові слова: кольорознавство; колір; дизайн зачіски; перукарське мистецтво. 


\title{
НЕКОТОРЫЕ ВОПРОСЫ ТЕОРИИ И ПРАКТИКИ ЦВЕТОВЕДЕНИЯ И ЕГО ПРИМЕНЕНИЕ В ПАРИКМАХЕРСКОМ ИСКУССТВЕ
}

\author{
Савицкая Елена Владимировна
}

Аспирантка, ORCID: 0000-0003-0905-4243, e.savitskaya1@gmail.com, Киевский национальный университет культуры и искусств, Киев, Украина

В статье проведен анализ развития цветоведения как научной основы практики искусства и дизайна. Целью работы является исследование цветоведения как комплекса научных знаний, сформированных на протяжении тысячелетий, а ныне - теоретической и практической подосновы для решения разнообразных творческих задач, в том числе в парикмахерском искусстве. Методология исследования состоит в анализе формирования и развития цветоведения как явления, несущего существенную информацию для науки и творчества, в том числе колористического дизайна. Для отслеживания становления, формирования, развития цветоведения использованы историко-сравнительный и хронологический методы, для упорядочения и систематизации разнородных материалов - системный подход, для изучения вклада в развитие цветоведения деятелей науки и искусства биографический, для сравнения исторических данных - компаративный. Научная новизна исследования состоит в анализе влияния цветоведения на производственную и творческую практику колористического дизайна прически. Выводы. Выснено, что цветоведение как научное знание объединяет дисциплины природоведческой и гуманитарной сфер, что является подосновой для современного научного подхода к работе с цветом с учетом его оптических, цветовых и других свойств. Развитие цветоведения проходило в течение столетий, охватив эпохи античности, Возроджения, Новой, Новейшей истории, современности. Современное цветоведение базируется на сочетании знаний о физических (свет) и психофизиологических (зрение, эмоция) явлениях, что нашло отражение в физике, психологии, физиологии, культурологии, искусствоведении. Дизайн, в том числе парикмахерское искусство, обращаясь к результатам междисциплинарных исследований, отражает высокий уровень современного осмыслення цвета и его широкое применение в прическе.

Ключевые слова: цветоведение; цвет; дизайн прически; парикмахерское искусство. 